\title{
Cities' Strategies for Sustainable Food and the Levers They Mobilize
}

\author{
Jess Halliday with Wendy Mendes (Box Contributor)
}

There is a growing realization of cities' vulnerability to the problems posed by the food system that are described in the chapter "Urbanization Issues Affecting Food System Sustainability". Reliance on globalized supply chains puts food provisioning arrangements at risk from environmental, political or economic disruptions. Cities lack productive space to produce all the food needed to feed their populations (Steel 2008, 2012), yet cities in less developed countries of the Global South will host most of the growth in world population, projected to reach 9.1 billion by 2050 (FAO 2009). Household food insecurity (or food poverty) is a major issue in many cities in developing countries, but incidence has also risen in the Global North, where the long-term effects of the 2008 economic downturn are still felt. Moreover, urban consumers are increasingly disconnected from the origins of their food (see chapter "Urbanization Issues Affecting Food System Sustainability"), and modern cities are obesogenic environments where calorie-dense/nutritionally-lacking food is cheap and available, but where opportunities for physical activity are limited (Morgan and Sonnino 2010). Consequently, diet-related ill-health has reached epidemic levels.

While the capacity of cities to implement food policies has ebbed since the end of the Middle Ages (see chapter "History of Urban Food Policy in Europe, from the Ancient City to the Industrial City"), a small but increasing number of cities around the world are devising policies to address food-related problems or to mitigate their effects. This chapter describes the range of cities' aims in so doing, while drawing on existing literature to develop a broad typology and exploring relations between cities and their hinterlands, since many policies have repercussions that are felt beyond the boundaries of cities or involve external actors. The analysis in this chapter focuses on the levers and instruments that are employed by cities to meet their objectives, with attention to the importance of cross-domain working and determining

\footnotetext{
J. Halliday $(\square)$

CIRAD, UMR MOISA, Montpellier, France

e-mail: j.halliday@ruaf.org 
what is possible within each city's context. A typology of governance models for cities' food-related interventions is then outlined, and the need to draw on capabilities of civil society and the private sector to overcome barriers faced by the public sector is highlighted. Several ways in which the success of urban actions can be measured are subsequently discussed. Finally, two possible future directions for cities' role and influence in the food system are identified.

\section{Objectives of Urban Food Policies and Challenges of Urban-Rural Relationships}

Any attempt to find homogeneity in the intentions behind cities' food policy efforts is fraught with difficulty.

Firstly, political and socioeconomic histories have led to differences in perspectives and priorities with regard to food. These differences are apparent from city to city but are most evident when comparing cities in developed and less developed countries. In many places in the Global South, food security is supported by close connections between rural and periurban producers and urban consumers, and (often informal) urban agriculture, but migration to cities means connections are failing and encroaching urbanization causes land-use conflicts. Prosperous cities of the Global North, on the other hand, tend to rely heavily on the globalized, industrial food system that transports ingredients and composite products across continents. Yet in developed countries there are wide inequalities in access to healthy, nutritious and quality food. Food insecurity is often manifested as obesity rather than starvation, while 'precarious food situations', as defined by Dominique Paturel (Paturel et al. 2015), are marked by a lack of physical, economic or cognitive access to healthy and nutritious food.

Secondly, there is a lack of consistency in how cities express their aims, their entry points and framing of the issues. It has been proposed that cities' main aim is to ensure future food security (Morgan and Sonnino 2010; Sonnino 2014), which is a situation when, "[...] all people, at all times, have physical and economic access to sufficient safe and nutritious food that meets their dietary needs and food preferences for an active and healthy life" (World Food Summit 1996). The phrase "food security' seldom appears in the titles of urban food strategy documents in the Global North, as Roberta Sonnino (2014) found in her discourse analysis of 15 such strategies, but it tends to be implicit and embedded within health and sustainability language. While there is sometimes direct reference to food security in the body of these documents as one of several priority themes, it is usually framed as a health or food access issue.

Thirdly, the aim of a food-related policy is not always articulated separately from the levers to be employed to implement it. Sometimes a city's entry point is not the identification of a problem to be addressed, but rather an aim, a strategy, or a desire to implement an available instrument (as discussed in greater detail in chapter "Reconciling Sustainability Issues and Urban Policy Levers"). 
Fourthly, not all food-related policy is framed as such, but the headline aim can be wider, with food being one of several strands. This is the case for Medellin's Todos por la vida ('everyone for life') policy, which builds the city's infrastructure to alleviate the effects of the civil war, with an ethos of greening, biodiversity and social inclusion. The wider programme includes food security enhancement strategies (Laidlaw 2015).

Despite these difficulties, nine food-related aims were identified in a review of literature on cities' food policies published in 2015 or earlier. ${ }^{1}$ These aims are presented in Table 1, with examples of policy levers and instruments through which 11 cities work towards their aims. Levers are defined as policy domains or responsibilities that reside at the local level and which usually have an associated local government department or service. Instruments are the procedural means that the departments or services have at their disposal (see chapter "Reconciling Sustainability Issues and Urban Policy Levers").

Regeneration, the first aim in Table 1, uses food-related activities to revitalize the social fabric of an urban area that has become run-down following a crisis. In Detroit, urban agriculture could be a means of regenerating the city after its economic collapse, as Detroit is exempt from the State Right to Farm Act which otherwise prohibits agriculture in urban areas (Detroit Future City 2012). In Medellin, the crisis was sociopolitical, and funding was provided for urban agriculture projects by the State electricity provider as part of a long-running urban development programme (Laidlaw 2015). In both of these examples, urban agriculture is central to regeneration efforts and can address problems of physical or economic access to healthy food, while boosting cognitive reconnection with food sources and food production, thereby helping to improve diets.

Regeneration is closely connected to economic development, the second aim, as diverse and prosperous food businesses reinvigorate the economy through their own activities and by attracting customers for all local businesses. Within cities, viable food enterprises contribute to local economic prosperity through taxable revenues and job creation, with an emphasis on good jobs that pay a living wage and offer safe and fair conditions and training in healthy food preparation and sustainability (Freudenberg and Silver 2013). In London, funding and campaigning for food apprenticeships by the Greater London Authority helps tackle joblessness whilst creating a pool of skilled professionals (Johnson 2013). Moreover, as in Barcelona, investment in food market infrastructure yields benefits within the city and regionally. It improves food access in cities, while securing access to the profitable urban market for regional producers, thereby helping to overcome long-term resilience problems by ensuring that the local food supply is viable (Forster et al. 2015).

\footnotetext{
${ }^{1}$ Academic papers were identified through a search of City University London's library online using the terms 'food policy' and 'city' or 'urban', and 'food policy council', and 'urban food strategy'. Non-academic literature was identified through online searches (Google) using the same terms. Policy documents were sourced where the author had prior awareness of food policies. The policies included in Table 1 are examples and not a definitive list of cities' food-related policies.
} 
Table 1 Examples of cities' aims, levers and instruments

\begin{tabular}{|c|c|c|}
\hline Aims & Levers & Instruments \\
\hline \multicolumn{3}{|l|}{ 1. Regeneration } \\
\hline Detroit, USA & Planning & Urban agriculture zoning regulation \\
\hline Medellin, Colombia & Urban development & Funding urban agriculture \\
\hline \multicolumn{3}{|c|}{ 2. Economic development } \\
\hline Barcelona, Spain & Market management & Investment in food market infrastructure \\
\hline London, UK & Economic development & Campaigning, funding food apprenticeships \\
\hline \multicolumn{3}{|c|}{ 3. Food supply resilience } \\
\hline $\begin{array}{l}\text { Belo Horizonte, } \\
\text { Brazil }\end{array}$ & $\begin{array}{l}\text { Agricultural } \\
\text { development }\end{array}$ & $\begin{array}{l}\text { Technical and financial incentives for } \\
\text { agriculture; } \\
\text { Production-consumption schemes; } \\
\text { Promoting urban agriculture }\end{array}$ \\
\hline \multicolumn{3}{|c|}{ 4. Food security and access } \\
\hline $\begin{array}{l}\text { Belo Horizonte, } \\
\text { Brazil }\end{array}$ & Social welfare & $\begin{array}{l}\text { Subsidies for canteens and staple foods; } \\
\text { School food funding }\end{array}$ \\
\hline Medellin, Colombia & $\begin{array}{l}\text { Business/trade } \\
\text { Social welfare }\end{array}$ & $\begin{array}{l}\text { Price regulation; } \\
\text { Public-private partnerships; } \\
\text { Participatory budgeting for emergency food }\end{array}$ \\
\hline Toronto, Canada & $\begin{array}{l}\text { Urban development } \\
\text { Public health }\end{array}$ & $\begin{array}{l}\text { Funding for urban agriculture; } \\
\text { Subsidies for mobile fruit and vegetable } \\
\text { vending }\end{array}$ \\
\hline
\end{tabular}

5. Environmental protection

\begin{tabular}{|c|c|c|}
\hline Malmö, Sweden & Public canteens & $\begin{array}{l}\text { Procurement contracts; } \\
\text { Training }\end{array}$ \\
\hline London, UK & London 2012 Olympics & Contracts specifying sustainability criteria \\
\hline \multicolumn{3}{|l|}{ 6. Public health } \\
\hline New York, USA & $\begin{array}{l}\text { Public health } \\
\text { Public procurement }\end{array}$ & $\begin{array}{l}\text { Regulation on trans fats, calories on menus; } \\
\text { Executive order on nutrition standards }\end{array}$ \\
\hline Waltham Forest, UK & Planning & Planning restriction on food takeaways \\
\hline \multicolumn{3}{|l|}{ 7. Food safety } \\
\hline Hanoi, Vietnam & Retail modernization & $\begin{array}{l}\text { Public-private partnerships; } \\
\text { Private standards }\end{array}$ \\
\hline \multicolumn{3}{|l|}{ 8. Social inclusion } \\
\hline Rosario, Argentina & Planning & $\begin{array}{l}\text { Public land use designation for urban } \\
\text { agriculture; } \\
\text { Tax relief for private landowners; } \\
\text { Participatory budgeting }\end{array}$ \\
\hline \multicolumn{3}{|l|}{ 9. Food culture } \\
\hline London $\mathrm{UK}^{\mathrm{a}}$ & Mayoral support & $\begin{array}{l}\text { Funding on urban agriculture; } \\
\text { Support campaign }\end{array}$ \\
\hline
\end{tabular}

${ }^{a}$ Social and cultural aspects of London food is one of several themes in the London Food Strategy, while the others are covered under other identified headings 
The next two aims, food supply resilience and food security and access, are also connected. Resilience is a precursor to food security as it ensures that the food system can withstand macro-level threats, be they economic, sociopolitical or environmental. The example of Belo Horizonte bears similarities to the market infrastructure development policy in Barcelona, since agricultural development is intended to ensure local production will be able to meet demand in the long term. Food security and access means ensuring that nutritious food is available to the entire community. In Medellin, policy efforts include the provision of emergency food aid under social welfare, and price regulation (Laidlaw 2015). In Belo Horizonte, social welfare efforts are focused on subsidizing canteens and funding school meals (Rocha and Lessa 2009). Physical access can be improved by bringing food supply into underserved areas, such as Medellin's public-private partnerships to ensure that businesses operate in food deserts (Laidlaw 2015). In Toronto, physical access is addressed through integrating urban agriculture into residential areas, and via subsidizing vans to deliver fresh vegetables and fruit in underserved neighbourhoods (Mah and Thang 2013).

The environmental protection aim also promotes long-term resilience as any harmful environmental impacts of food production, distribution and waste disposal can impair future food security. Environmental problems hinge largely on the interface between production and demand within cities. On the one hand, protecting the environment comes down to informing producers about agricultural technologies that are more sustainable and encouraging their adoption. On the other hand, there is a need to create demand for food produced using environmentally-sound practices, as achieved in both Malmö (Anderson and Nillson 2012) and London (London, 2012 2009), where agricultural production practices are specified in procurement and catering contracts.

The public health improvement aim is intended to directly address problems caused by long-term consumption of inappropriate foods, as opposed to the food safety aspects of public health discussed below. Public health is linked to the food security aim, as optimum public health is an outcome of access to sufficient, safe and nutritious food, but enabling public is not just about preventing malnutrition. The ubiquity of cheap, convenient food of poor nutritional quality is a driver of the obesity crisis and diet-related disease (Morgan and Sonnino 2010). Public health measures tend to fall into two categories: education and consumer awareness campaigns to enable informed food choices; and altering the food environment to promote healthier options or limit unhealthy options. The requirement of calorie labelling on restaurant menus in New York is a prime example of the first category, while the second is illustrated by city Health Code amendments prohibiting artificial trans fats in takeaway foods (Libman 2015). Planning restrictions on the opening of new takeaway restaurants near schools and playgrounds in the London Borough of Waltham Forest is a further example of a change in the physical environment (GLA and CIEH 2012). Food safety is a basic facet of public health, although it can also be a specific aim geared towards avoiding the immediate, and often catastrophic, effects of poor hygiene or lack of infrastructure on human health. This is the case with traditional wet markets in Hanoi (Vietnam) that were perceived to 
pose a food safety hazard since they do not meet the private standards of modern supermarkets. Consequently, the city's retail modernization policy framework, which favours public-private partnerships, has led to their closure and replacement with supermarkets (Wertheim-Heck et al. 2015).

Social inclusion and food culture - the last two aims - seek to remedy the problem of consumers' cognitive and cultural detachment from food. Social inclusion concerns the social and participatory nature of eating, preparing or growing food. It strives to deal with inequality, such as in Rosario, where the planning system is used to provide access to public or private land for those who would otherwise be excluded from food growing (Roitman and Bifarello 2010). Finally, the food culture aim seeks to foster conscious food choices. In London, Mayoral support has enabled programmes to educate the public and raise awareness about sustainability and healthy food. Events are organized to encourage food diversity, from both nutritional and cultural standpoints, particularly in light of the ethnic diversity within the city (GLA 2011).

Each of the aims in Table 1 ostensibly seeks to shape the food environment within the city for the benefit of urban residents. However, several of them have effects or require action outside of the city limits too-notably economic development, food supply resilience, food security and access, and environmental protection. This is because the food system is an intrinsic and non-divisible whole made up of all stages of food supply, as well as contextual influences, inputs, outcomes and outputs (Lang et al. 2009; Lang and Heasman 2015). Moreover, as the food system is not geographically bounded, all places of human settlement, their demands and impacts have knock-on effects throughout the system, worldwide (Marsden 2013). Despite this, urban and rural affairs historically have been regarded as discrete disciplines, with the former being a locus of consumption and the latter of production (Dupuis and Goodman 2005). As local administrative boundaries often stop at the city limits, further discussion on the links between cities and periurban and rural areas is warranted.

The City Region Food System (CRFS) concept is an attempt to bridge the longstanding divide between urban and rural concerns (Dupuis and Goodman 2005; Cohen and Garrett 2010). In 2013, CRFSs were defined as encompassing:

[...] a complex network of actors, processes and relationships to do with food production, processing, marketing and consumption that exist in a given geographical region that includes a more or less concentrated urban centre and its surrounding periurban and rural hinterland; a regional landscape across which flows of people, goods and ecosystem services are managed (www.cityregionfoodsystems.org). ${ }^{2}$

Local and regional provisioning is an operational facet linking urban consumers with rural producers via food value chains, but the intention is wider-to maximize ecological and socioeconomic links and to foster food system co-governance by both urban and regional actors (Jennings et al. 2015). In this way, CRFSs avoid falling into the 'local trap' that assumes local is an inherently good scale for action,

\footnotetext{
${ }^{2}$ Definition by a collaborative partnership of interested organizations.
} 
either by considering localisation of supply chains as an aim in itself or by failing to explore the role of other scales in configuring urban food environments (Libman 2015; Born and Purcell 2006; Winter 2003).

However, while CRFS is a helpful concept that is being applied in empirical settings, its applicability is nonetheless contingent on two factors: the situation of the city within an agricultural basin; and the existence of regional institutional structures and their willingness to engage with the city.

Firstly, according to the definition, a 'city region' comprises an urban centre and a periurban and rural hinterland, with provisioning links dependent on the latter being a productive agricultural basin. The Dutch city of Rotterdam, with arable, dairy, and greenhouse horticulture production in the surrounding province of South Holland, is a good example of a CRFS (Van der Schans 2015). On the other hand, La Paz (Bolivia), where the high elevation and low temperatures limit agricultural production and most provisions are brought in from elsewhere (Velasco and De Vrieze 2015), cannot be considered as a CRFS centre. Indeed, Braudel (1979) points out that, historically, cities were not systematically established at the centre of a productive region that could serve them, but rather access to trade routes-usually via a port-was crucial to the most powerful cities, allowing them to draw provisions from elsewhere.

Secondly, co-governance between urban and regional actors can depend on the existence of governmental and institutional structures at the regional level, and political will within them. In the UK, England's regional layer of government was dismantled by the coalition government that came to power in 2010. The Netherlands, on the other hand, is divided into 12 regions with clear policy responsibilities, providing a framework for cities to engage with the wider region on food issues. In France, meanwhile, the regions have expressed an interest in more territorialized food systems and have suggested instruments for regional authorities to contribute to sustainable food regions, such as regional marketing labels and technical or financial support (ARF 2014; Braine-Supkova and Gaspard 2015). This does not make regions automatic vehicles for coordinated cross-boundary food policy, however. At the metropolitan level, meanwhile, there is considerable potential for cooperation across administrative boundaries. In the Montpellier Méditerranée Métropole, 31 municipalities are cooperating to develop a food strategy (see chapter "Reconciling Sustainability Issues and Urban Policy Levers"). Similarly, in England, the emergence of Greater Manchester as a pilot city region (following the demise of the English regions) may enable integrated food policy implementation across a larger area (Halliday 2015).

\section{Urban Food Policy Levers and Constraints on Their Use}

Alongside the broadly categorized aims, Table 1 also sets out levers and instruments employed by cities in pursuit of their aims. 
The examples of Belo Horizonte, Medellin, Toronto and New York show that the levers and instruments to address an aim are not always limited to one policy area, but several can be employed together. This is because food is not the sole responsibility of a single local government department but different aspects are directly or indirectly handled by different teams (such as public health, economic development, planning, education, etc.). On the one hand, this means there is potential for a more powerful multi-pronged effort, such as in Toronto where food access interventions (e.g. subsidized mobile fruit and vegetable vans) are complemented by public health efforts to boost food literacy, and as a consequence demand for healthy food (Mah and Thang 2013). On the other hand, unless there is recognition of the crossdomain nature of food and a concerted effort towards coordination, there is a danger that each department will look no further than the implications on its own remit (Pothukuchi and Kaufman 1999).

Recognition of the cross-domain nature of food is increasingly seen as the best practice, although it is not yet ubiquitous. Coline Perrin and Christophe Soulard (2014) and Caroline Brand (2015) report that in France to date there is little recognition that food is a local policy area per se, or that food issues require concerted integrated action at the local level. A common intention of food policy councils ${ }^{3}$ that have emerged over the last 20 years in the Global North (particularly in Englishspeaking countries) is the intention to find and exploit synergies between different public sector areas involved with food (Wiskerke and Vilojoen 2012). One area often serves as a hook or entry point to gain initial local government buy-in in keeping with civic priorities. The initial framing of both the Toronto Food Policy Council in Canada and the London Food Board in the UK was public health but both maintained wider underlying policy objectives on food access, affordability, education and production. This undercurrent of cross-domain activity prevents issues being overlooked and enables them to be brought to the fore if priorities change (BlayPalmer 2009; Mah and Thang 2013; Reynolds 2009; Morgan and Sonnino 2010).

These examples and best intentions notwithstanding, achieving synergies between policy areas is not always easy. Firstly, each area or department has its own procedures and ways of working (tacitly or explicitly agreed) and language that may not be understood in co-working situations. Departments do not always recognize the relevance and value of food to their core work, nor that food is a cross domain issue over which there is much potential for inter-departmental working (Wegener et al. 2013). Rigid line management structures can also limit the potential for senior staff to take part in strategic policy work with other departments (Yeatman 2003).

Secondly, the precise distribution of powers and responsibilities at the local level varies between national settings. The principle of subsidiarity (which has become a fundamental element in the functioning of the European Union since the early 1990s) holds that policies should be formulated and enacted at the most local level possible and higher levels should step in only if the required action cannot be

\footnotetext{
${ }^{3}$ Morgan (2014) counted 193 food policy councils in North America in 2012, while in the UK the term 'food partnership' is more prominent and some 40 food partnerships have been founded in local government areas in recent years.
} 
achieved. This seems to give local governments carte blanche to devise food policies as they see fit. However, the EU protocol on applying the principle of subsidiarity relates to EU institutions and Member States (European Union 2010), while there are only recommendations on the division of responsibilities between national and sub-national levels whereby each state can devise its own system (Council of Europe 1995). No ideal level is prescribed for each policy area because local authorities vary in size and resources.

Moreover, the role of local government and its leaders with regard to the national level differs between countries. In some, local government has full legislative power in locally-managed domains; in others it has the power to introduce a policy that is not the specific responsibility of another level or entity; while in others local government largely delivers services or commissions on behalf of the national level. A comparison of the powers of the mayors of New York and London with regard to healthy eating illustrates these differences. The Mayor of New York has regulatory powers that have enabled him to introduce restrictions on trans fats in fast food establishments and calorie labelling in chain restaurants (Libman 2015). His London counterpart has no legislative power and his public health remit is limited largely to advocating conducive policies at the borough level, ${ }^{4}$ and seeking voluntary measures (Halliday 2015; Morgan and Sonnino 2010). In France, cities lack the political weight of their European and American counterparts, with responsibility for food residing at the national or EU level (Perrin and Soulard 2014). Meanwhile, in North African countries, agricultural policies for food security are national rather than local (Soulard et al. 2015).

A third problem in the use of public sector levers is that options within various policy areas are subject to multilevel governance constraints. European public procurement policy is a prime example: while procurement for all locally-managed public services takes place locally, the EU public procurement directive stipulates that calls for tender may not specify preferred place of origin or use the word 'local' (Morgan and Sonnino 2008). Planning policy in England is a further example: each local government authority produces its own planning strategy which must be in keeping with the National Planning Policy Framework (NPPF). Consequently, although the London Borough of Waltham Forest introduced restrictions on new unhealthy fast food outlets near schools and playgrounds, NPPF removed the need for prospective fast food outlets to obtain permission to change the use of business premises, thus making Waltham Forests' new policy hard to implement. Such barriers highlight the need for local government to engage with multiple levels and advocate conducive framing policies.

In light of the arbitrary application of the principle of subsidiarity, differing roles for local government with regard to the national level, and multilevel framing constraints, it is not possible to definitively identify which policy areas are best handled at which level. Planning and public procurement have been identified as two areas in which the local level has the greatest potential to address food issues (Sonnino 2014; Sonnino and Spayde 2014), but there are other policy areas related to food

${ }^{4}$ London has 32 boroughs, each with its own local government. 
Table 2 Food-related policy areas

\begin{tabular}{l|l}
\hline Policy area & Relevance to food \\
\hline $\begin{array}{l}\text { Planning, infrastructure and } \\
\text { urban development }\end{array}$ & Land use, location of food outlets/retail \\
\hline Public transport and roads & Infrastructure for food distribution and retail market access \\
\hline Local economic development & $\begin{array}{l}\text { Supporting food businesses, job creation, development of } \\
\text { skills }\end{array}$ \\
\hline Local finance administration & $\begin{array}{l}\text { Tax on food businesses, budgetary provision for services and } \\
\text { subsidies }\end{array}$ \\
\hline Social welfare services & $\begin{array}{l}\text { Food aid (food vouchers and subsidies), emergency food } \\
\text { provision }\end{array}$ \\
\hline Public health & $\begin{array}{l}\text { Diet-related preventive health, education and targeted } \\
\text { campaigns }\end{array}$ \\
\hline Education & Food skills and culture \\
\hline Public procurement & Food served in public canteens and institutions \\
\hline Environmental sustainability & $\begin{array}{l}\text { CO }{ }_{2} \text { emissions from production and distribution, natural } \\
\text { resource use, biodiversity preservation }\end{array}$ \\
\hline Environmental health & $\begin{array}{l}\text { Implementation of food safety regulations, environmental } \\
\text { conditions }\end{array}$ \\
\hline Waste management & Redistribution of surplus food, composting and recycling \\
\hline &
\end{tabular}

where the local level may have a role, be it devising policy, interpreting/implementing policy from higher levels, or service provision. These are set out in Table 2.

Actors in each city are advised to reflect upon the applicable national model for local government and policy areas that can be leveraged, while acknowledging the constraints and barriers faced. By being realistic, they may find ways to remove the barriers (e.g. through negotiation, relationship building and subtle influence) or, where barriers are immutable, to identify creative workarounds to achieve the same results. These workarounds can include drawing on the resources, levers and instruments of civil society and private sector actors who support the objectives, but who are not subject to the same institutional constraints. The prospect of non-public sector levers and instruments calls for an analysis of the governance of city food policy initiatives.

\section{Involvement of Different Sectors and Respective Governance Models}

While so far this chapter has focused on public policy to address food-related problems, this section discusses the involvement of civil society and the private sector. Three governance models, each with variations, are outlined. Over the last 30 years, the shift to governance (particularly in developed countries) has brought the private sector and civil society into the policy-making process. This should not be interpreted as meaning that the State is handing over power (Pierre and Peters 2003), but 
rather that the State no longer 'rows' (i.e. delivers services or makes decisions unilaterally) but instead 'steers' using tools such as monitoring, cultural persuasion, financing, and a reserved right to intervene (Stoker 2000). This shift has taken place in every policy domain and means that the food system overall is not governed solely by top-down regulations. It is subject to contested governance in which the public and private sectors and civil society cooperate, but also compete for influence. However, the three sectors are not always perfectly represented when it comes to food policy development and implementation at the local level.

There is general agreement that political buy-in to food policy at the local level is critical to achieve change (Orlando 2011; Schiff 2008). Many commentators have nevertheless highlighted the benefits of civil society working alongside local governments. In non-Anglo Saxon contexts, Perrin and Soulard (2014) underline the need to conduct studies on forms of civil society involvement in food policy and to assess their contribution. If a food policy council only involves the public sector with no civil society ballast, there is a danger it will be unable to propose policy changes to the system within which it operates. As noted above, civil society and private sector actors bring their own arsenals of resources and instruments to complement those of the public sector. Using these, they can exercise agency, i.e. "act consciously and, in so doing to attempt to realise his or her intentions" (Hay 2002, p. 94), so as to overcome barriers posed by public sector institutional frameworks, e.g. inhospitable policy framing in multilevel governance or immutable procedures and received language (Halliday 2015). Civil society involvement is a key principle of food policy councils, which are groups of actors from multiple sectors. The latter meet regularly and their activities include formulating and advocating policy approaches, raising awareness, knowledge brokerage, and monitoring progress. Civil society brings insight and energy (Derkzen and Morgan 2012), offers resilience in the face of electoral change (Wiskerke 2009; Morgan and Sonnino 2008), and can provide specialist food knowledge and experience (Wekerle 2004).

As for the private sector, almost all food passes through the hands of at least one private enterprise on its route from producer to consumer, yet Harper et al. (2009) point out that food businesses are often un- or under-represented in food policy groups, and suggest that if they are not engaged from the start it is difficult to bring them in later if decisions have already been made that are not seen to be in their interest. This poor representation of food businesses could be explained by the perception that local food policy is entirely opposed to the global food system operations, with aims and objectives that are incongruent with those of business. However, a change in business practices has repercussions throughout the supply chain. Hence, local food policy groups should ideally include diverse businesses of different sizes, values, and activities to be able to initiate effective system change (Halliday 2015).

Food policy councils are the first governance model for local food policy. As a minimum they include actors from the public and civil society sectors, but there is much internal diversity in how they are initiated and run. Some, such as Manchester Food Futures in the UK, were initiated via top-down processes, while others, like the London Food Programme, were formed through a combination of top-down and 
bottom-up energy (Reynolds 2009). Where initiation is top-down, questions remain about when civil society and the private sector are to be brought in, who decides which organizations are eligible and on what criteria. If they join too late, they may struggle to achieve ownership of a preset agenda. The institutional positioning of food policy councils also varies. Some are hosted within local government structures, e.g. the Toronto Food Policy Council is embedded within the public health team (Blay-Palmer 2009). Others occupy an independent space outside local government, like the Bristol Food Policy Council which, nonetheless, still involves public sector actors (Carey 2013). Finally, the nature and degree of civic leaders' commitment ranges from explicit mayoral support (as in London), to adoption of a food strategy or motion (as in Manchester), to providing budget or in-kind support such as meeting rooms or officers' participation during working hours.

Despite the popularity of the food policy council model, it is by no means the only type of urban food policy intervention. A second type is found in some cities, where the intervention is formally rooted in a public mandate to take responsibility for the food system, albeit with input or practical contributions from civil society, the private sector, or universities and research institutes. In San Francisco in 2009, the then-Mayor Gavin Newsome issued an executive directive making the food system the explicit responsibility of the city government. In La Paz (Bolivia), the 2014 'Autonomous Municipal Act N ${ }^{\circ} 105$ on Food Security', the goal of which is to secure the right to food for all citizens, was prompted by campaigning by civil society groups. The benefit of high level mayoral commitment is that it enables (and often obliges) departments and agencies to review their food-related policies. Elsewhere, a local government entity has been set up to coordinate integration between food-related policy domains, as is the case with the Municipal Secretariat for Food Policy and Supply in Belo Horizonte, which engages the private sector and civil society over implementation (Rocha and Lessa 2009). As for universities, the development of a city-region agriculture and food production policy in Montpellier (France) has involved a team of researchers working alongside the public sector (Soulard et al. 2015; chapter "Reconciling Sustainability Issues and Urban Policy Levers"), while researchers from the University of Pisa (Italy), with the agreement of the provincial administration, initiated multisector discussions over developing a food plan for the city (Di Iacovo et al. 2013).

While a coordinating entity is helpful, it is not a prerequisite of interventions that have positive impacts across policy areas. For instance, the city council in Ourense (Spain) initiated an agricultural land-use policy of establishing urban orchards. This initiative was intended primarily to boost citizens' education and employment skills using financial instruments to facilitate access to private land, but it has also brought documented environmental, social and economic benefits (Oursense City Council 2013). The London borough of Waltham Forest's planning restrictions on unhealthy fast food outlets, as mentioned above, brings both public health and environmental benefits.

A third type of urban food policy initiative that is worthy of mention consists of civil society interventions with varying degrees of organization. In some cases, food activities are part of a wider social movement, such as Transition Towns through 
Table 3 Overall types and variations of urban food policy interventions

\begin{tabular}{l|l}
\hline Types & Variations \\
\hline Food policy council & $\begin{array}{l}\text { Top-down or bottom-up initiatives (or both) } \\
\text { Hosted within local government or outside } \\
\text { Nature and extent of local government support }\end{array}$ \\
\hline $\begin{array}{l}\text { Formal public-sector } \\
\text { mandate }\end{array}$ & $\begin{array}{l}\text { Executive directive or law } \\
\text { Local government entity to coordinate integration of different } \\
\text { areas } \\
\text { Individual policies with cross-policy domain implications }\end{array}$ \\
\hline Civil society intervention & $\begin{array}{l}\text { Part of a wider social movement } \\
\text { Set up by an established organization with funding } \\
\text { Guerrilla movement }\end{array}$ \\
\hline
\end{tabular}

which grassroots communities seek to build resilience in response to peak oil, climate change, and economic instability (Morgan 2009). In other cases, food projects are instigated by established organizations, usually upon receipt of funding. While such projects initially lack local government support, they might clinch it once they are established and yielding positive results. For instance, in Porto Alegre (Brazil), the bottom-up guerrilla gardening initiative of planting fruit trees has been accepted and maintained by municipal workers (Abelman 2015). This case is reminiscent of Incredible Edible Todmorden in the UK, which started off as community movement and has earned the support of public bodies while serving as a template for integrating agriculture into city environments around the world (Warhurst 2012).

The three types of urban food policy described above and their variations are summarized in Table 3.

The governance model for an urban food policy initiative often does not come down to a choice by the initiator, and it would be inappropriate to recommend a one size fits all model to be universally applied to all places and circumstances. Rather, different models are suitable and possible in different settings, depending on variables such as local government structure, political will, and social capital levels. The high social capital levels in Bristol (UK) have enabled the Bristol Food Policy Council to secure some influence over policy making despite residing outside of local government. Meanwhile, in Manchester-a city with a relatively conservative culture - the Food Futures programme could not have operated effectively had it not been embedded within the Manchester City Council (Halliday 2015).

\section{Ways to Assess the Success of Urban Food Policies}

The success of an intervention will ultimately need to be assessed irrespective of the governance model, aims, levers and instruments employed. This means coming up with a definition of the success of a food policy. However, it is hard to judge the impact of a policy initiative unless indicators and evaluation criteria are defined at the start (Sonnino 2013; Burgan and Winne 2012), especially because food-related 
issues are complex and there can be non-food contributing causes or mitigating factors. For example, if the aim is to improve public health or reduce negative environmental impacts using public procurement as a lever, a measureable indicator could be the number of school canteens or other public bodies subscribed to a certification scheme. If the aim is to improve the food economy using more local food sourcing as a lever, indicators could be the land area devoted to food production, profits of local food enterprises, or their ability to remain in business. A problem with indicators is that they are retrospective and require a period of time before success can be measured, at which point it could be too late to deal with any barriers. One way of overcoming this problem is to assess the process of establishing a governance body, while determining its role and mission and implementation as it is taking place (Burgan and Winne 2012).

Kenneth Dahlberg (1995) also offered a different interpretation of success by asking, "has everything been done that was possible in that context?". This highlights that the impact of policy efforts is dependent upon circumstances and subject to constraints within the local policy environment and in multilevel framing of policy domains. It is prescient of the strategic urban governance capacity (SUGC) approach employed by Wendy Mendes (2008) and Brent Mansfield (Mansfield and Mendes 2013) to explore factors that can affect the capacity of local government to develop and implement a food strategy (see this chapter, Box 1).

Another way of judging the success of an initiative is to assess its wider impact on the food system, with scaling up leading to reconfiguration of food provisioning arrangements and impacts outside the boundaries of the city or its immediate surroundings. Given the current enthusiasm for urban food policy and CRFS, there is a danger of giving the impression that food system problems can be solved by cities alone. Roberta Sonnino (2014) has underlined the ambitious claims by several cities of 'world leadership' with regard to urban food strategies in the Global North, which imply not only that they are among the first to have a comprehensive food strategy but also that they have the means to bring about larger-scale food system change. Actually, inhospitable multilevel governance can present barriers to largerscale change (Barling et al. 2002) and can hamper the ability of an initiative to flourish in the long term (Morgan et al. 2006). By and large, multilevel food policy remains predominantly neoliberal, albeit with highly contested governance. To date there is little evidence of larger scale change prompted by any city's food-related policy, with two notable exceptions: Belo Horizonte's Fome Zero (zero hunger) strategy, which was instrumental in the institutionalization of the right to food at the national level (Rocha and Lessa 2009); and New York's trans fats directive, which prompted the Food and Drug Administration (FDA) to propose new rules that would eliminate trans fats in the US food supply (Libman et al. 2015).

Possible pathways to higher level influence include the involvement in local level food policy of actors who have political influence at other levels (e.g. public figures or big business representatives), and greater cooperation between cities. There is already evidence of cities learning from each other and sharing experiences, whilst remaining alert to the governance differences that limit direct policy transfer, as seen in the exchanges between London (UK) and Toronto (Canada) (Blay-Palmer 


\section{Box 1: Strategic Urban Governance Capacity Concept and Urban Food Policy Implementation Factors}

\section{Wendy Mendes}

The strategic urban governance capacity (SUGC) concept, as theorized by urban planning scholar Patsy Healey (2002), can be traced to the shift from government to governance, resulting in a blurring of distinctions between the State, market and civil society (Harvey 1989). Beyond this commonality, SUGC can be distinguished by its focus on "the creation of meanings for the city which make a contribution to creating and sustaining an imaginative, shared collective resource, which is richer and more inclusive" (Healey 2002: 1778). In this sense, SUGC is a lens through which fundamental questions can be asked about who and what cities are for, and who has the power to shape their trajectory (ibid.: 1779). The SUGC concept is productive for a number of reasons with regard to urban food policies and other complex sustainability challenges.

Firstly, it shows the extent to which impulses for change must be imagined before transformations can be achieved. This means that city governance analyses must foster attentiveness not only to governmental arrangements, but equally to wider urban concepts that new social and environmental mandates such as food policy imply. Although resilient food systems are among the most ancient of urban concerns, the relatively recent re-emergence of food on urban agendas puts a spotlight on assumptions about what counts as a 'legitimate' urban system, who participates in defining food system challenges, and the ways in which solutions are co-created. This is at least partly due to the unusually high number of stakeholders associated with food movements. These include coalitions concerned with ecological protection, public health, nutrition, anti-poverty, social inclusion, community capacity-building, participatory decision making and economic development. Although not without internal tensions, such a broad landscape of perspectives can enhance dialogue - and imaginings_-on contemporary city-building and civic engagement.

Secondly, the SUGC notion humanizes governmental institutions as sites of urban transformation and reveals that governance and policy making are deeply social processes (While et al. 2010; Mendes 2007, 2008; Mansfield and Mendes 2013). As Healey argues, no one agency has the power to produce the city, be it materially or symbolically (2002: 1785). An examination of governmental institutions through the lens of SUGC makes it possible to envision the potential to incubate new, sometimes radical, ideas and practices involving traditional and nontraditional stakeholders. These practices can cast light on city governance as "a border zone of trial and error" in which those involved assume new and expected roles (Appadurai 2001: 33-34). 
Box 1: (continued)

Another way to describe such an approach is what Dana O'Donovan and Noah Rimland Flower (2013) call "adaptive strategy", referring to the shift away from long held assumptions about strategy and planning as predictable, hierarchical and linear. In recognition of the complexity of our current economic, political and social systems, O'Donovan and Rimland Flower argue that the adaptive strategy allows for iterative problem solving characterized by collective decision making, rapid prototyping and experimentation (ibid.). Where urban food systems are concerned, the rise of large-scale urban farming, food business incubators, community food hubs, comprehensive municipal food strategies and other food-centred innovations, requires precisely this type of expanded capacity for experimentation and ability to test new solutions. Food system innovations often take place under conditions of ambiguous regulation, typically have few precedents, and involve the participation of non-traditional stakeholders. These innovations contribute to and are propelled by new understandings of governance, planning and policy making embodied in notions such as SUGC and adaptive strategy.

Thirdly, building on expanded of strategic planning notions, a SUGC approach to urban food policy disrupts institutional and sectoral silos that can impede systemic responses to complex sustainability challenges. As Healey writes, strategic planning efforts based on SUGC principles, "move from a position above and apart...to institutional locations within the flow...of urban life (Healey 2002: 1786). Results can include a challenge to centralized decision making, an increase in cross-agency collaboration, and a shake up of institutional silos (ibid.: 1787). For instance, in his analysis of the London food strategy, Reynolds (2009) examines the intention by the City of London to take "a holistic view of the food that the city produces, stores, delivers, sells, consumes and wastes" (ibid.: 417). Reynolds argues that the diversity of food issues addressed in London's strategy, combined with the wide range of agencies and sectors involved, is largely responsible for its continued relevance and success (ibid.: 417-418). He writes:

[...] rather than being split into a myriad of different silos, we believe a holistic approach is necessary: where decisions are made that not only consider the healthiness of a particular food offering but also its environmental impact, where social and cultural concerns are considered as much as economic concerns (ibid.: 424).

This aspect of SUGC raises a host of questions related to the implementation of responses to cross-cutting issues such as food policy. There is no one size fits all answer to this challenge, however a growing body of research examining the implementation of municipal food policy mandates and comprehensive 
Box 1: (continued)

municipal food strategies is building a rich knowledge base of insights (Mendes 2008; Rocha and Lessa 2010; Mansfield and Mendes 2013; Hatfield 2013; MacRae and Donahue 2013). Factors commonly explored in these studies include the role of the institutional location of food policy processes, staff and budget support, the degree of integration into normative mechanisms, champions supporting a new policy area, overall management, and the extent of meaningful partnerships with non-governmental actors.

Overall, SUGC clearly offers a useful lens that encourages new approaches to emergent issues such as food policy. Taken in conjunction with other tools and conceptual frameworks, SUGC can enhance the understanding of the strengths and challenges of taking a holistic systems approach to urban food policy and planning that is coordinated and collaborative.

\section{References}

Appadurai A (2001) Deep democracy: urban governmentality and the horizon of politics Environ Urban 13(2): 23-44

Harvey D (1989) From managerialism to entrepreneurialism: the transformation in urban governance in late capitalism. Geografiska Annaler Series B Hum Geogr 71(1): 3-17

Hatfield M (2013) Food policy \& programs: lessons harvested from an emerging field. Portland Bureau of Planning and Sustainability. http://www.portlandoregon.gov/bps/ article/416389. Accessed 10 Nov 2015

Healey P (2002) On creating the 'City' as a collective resource. Urban Stud 39: $1777-1792$

MacRae R, Donahue K (2013) Municipal food policy entrepreneurs: a preliminary analysis of how Canadian cities and regional districts are involved in food system change. http:// tfpc.to/wordpress/wp-content/uploads/2013/05/Report-May30-FINAL.pdf. Accessed 10 Nov 2013

Mansfield B, Mendes W (2013) Municipal food strategies and integrated approaches to urban agriculture: exploring three cases from the global North. Int Plan Stud 18(1): $37-60$.

Mendes W (2007) Negotiating a place for 'Sustainability' policies in municipal planning and governance: the role of scalar discourses and practices. Space Polity 11(1): 95-119.

Mendes W (2008) Implementing social and environmental policies in Cities: the case of food policy in Vancouver, Canada. Int J Urban Regi Res 32(4): 942-967.

O’Donovan D, Rimland Flower N (2013) The strategic plan is dead. Long live strategy. Stanf Soc Innov Rev. http://ssir.org/articles/entry/the_strategic_plan_is_dead._long_ live_strategy. Accessed 9 Nov 2015.

Reynolds B (2009) Feeding a world City: the London food strategy. Int Plan Stud 14(4): 417-424.

Rocha C, Lessa I (2010) Urban governance for food security: the alternative food system in Belo Horizonte, Brazil. Int Plann Stud 14(4): 389-400.

While A, Jonas AEG, Gibbs D (2010) From sustainable development to carbon control: the eco-restructuring of the State and the politics of urban and regional development. Trans Inst Br Geogr 35(1): 76-93. 
2009). New networks, such as the Sustainable Food Cities Network in the UK, and the 2015 Milan Urban Food Policy Pact, signed by over 100 cities around the world, can give cities a louder collective voice with regard to food policy. The local level could thus have more influence over higher levels of food system governance.

\section{Conclusion: Mobilizing Methodological Tools and Drawing Up an New Research Agenda}

This chapter has drawn attention to several important considerations for cities that seek to take responsibility for food. Firstly, it is helpful to identify pressing issues in the local context, as they can inform the overarching aims of food-related policy that resonate with top local government priorities. Secondly, the local context, including powers and capabilities that exist at the local level but are framed by multilevel governance, determines what can be done with respect to food and which levers can be utilized to achieve the aims. Thirdly, it is important to explore complementary levers and instruments across policy domains, as well as civil society and private sector contributions. There is a need for methodological and process tools that go beyond a check-box approach in order to assist cities in devising food policies that are appropriate and realistic within the local political economy. Failure to take the political economy into account is likely to impair the policy development and implementation process.

In addition to these lessons, this chapter has also identified two important issues concerning cities' food-related strategies. Firstly, questions have been raised about the appropriateness of cities seeking to (re)localise food provisioning, either as a specific aim or as a lever towards achieving other aims, if the city is not located within an agricultural basin and has historically forged longer-distance trade links. Secondly, there are questions over how far the local level can really contribute to systemic change, beyond just impacting food experiences within the urban setting and the immediate vicinity.

These issues each signal a possible new direction for the role and influence of cities within the food system. Regarding (re)localisation, there may be potential for cities to relocalize governance and control over supply chains instead of (or in addition to) territorial relocalization of food provisioning. This could be done through mutually beneficial partnerships or twinning with nearby or remote agricultural areas, investing in their production capacity, setting standards and offering a guaranteed market. There is a need for research into the conditions that would facilitate such innovation and any practical and ideological barriers that could arise. Test grounds are also required. These could include an initial focus on direct relationships to procure food for public canteens, or the extension and adaptation of current models to govern direct trading principles, such as Fairtrade and buyers' cooperatives. 
As for cities' influence at higher policy levels, on-going research is needed on the potential of the combined efforts of many cities to strengthen their collective voice. In particular, this includes monitoring the impact of initiatives such as the 2015 Milan Urban Food Policy Pact on the international food policy dialogue. Another possible way to exert a more systemic influence could be to seek and obtain buy-in of actors or organizations that are influential in multilevel governance but un- or under-represented in local food policy. These actors and organizations include major food businesses, lobby groups and political figures. To this end, research is needed to gain insight into the barriers to engaging these actors, such as accepted framings and definitions of sustainability and food security, accepted norms and ways of working, and the governance structures to which they are bound.

\section{References}

Abelman J (2015) Cultivating the City: infrastructures of abundance in Urban Brazil. Urban Agriculture Magazine 29: 62-64

Andersson G, Nillson H (2012) Policy for sustainable development and food for the City of Malmo. In: Wiskerke JSC, Viljoen A (eds) Sustainable food planning: evolving theory and practice. Wageningen Academic Publishers, Wageningen, pp 181-188

ARF (2014) Déclaration de Rennes: Pour des systèmes alimentaires territorialisés. http://www. diplomatie.gouv.fr/fr/IMG/pdf/de_claration-finale_ARF_cle81ab8a.pdf. Accessed 7 Aug 2015

Barling D, Lang T, Caraher M (2002) Joined-up food policy? The trials of governance, public policy and the food system. Soc Policy Adm 36(6):556-574

Blay-Palmer A (2009) The genesis of urban food policy in Toronto. Int Plan Stud 14(4):417-424

Born B, Purcell M (2006) Avoiding the local trap: scale and food systems in planning research. J Plan Educ Res 26(2):195-207

Braine-Supkova M, Gaspard A (2015) City region food systems on the political agenda in France. Urban Agriculture Magazine 29: 21-23

Brand C (2015) Alimentation et métropolisation: problématique vitale oubliée. Doctoral thesis in Geography, Université Grenoble Alpes, p 656

Braudel F (1979) The wheels of commerce: civilization and capitalism: 15th-18th century, volume 2. Armand Colin, Paris

Burgan M, Winne M (2012) Doing food policy councils right: a guide to development and action. Mark Winne Associates, Santa Fe, p 63

Carey J (2013) Urban and community food strategies. The case of Bristol. Int Plan Stud 18(1):111-128

Cohen M, Garrett J (2010) The food Price crisis and urban food (in)security. Environ Urban 22(2):467-482

Council of Europe (1995) Recommendation NoR.(95)19 of the committee of ministers to member states on the implementation of the principle of subsidiarity. Adopted by the committee of ministers on 12 October 1995 at the 545th Meeting of the Ministers' deputies, Council of Europe, Brussels

Dahlberg K (1995) Food policy councils: the experience of five Cities and one County. In: Joint meeting of the Agriculture, food, and human values society and the society for the study of food and society. Tucson, Arizona, 11 June 1994, p 22

Derkzen P, Morgan K (2012) Food and the City: the challenge of urban food governance. In: Wiskerke JSC, Viljoen A (eds) Sustainable food planning: evolving theory and practice. Wageningen Academic Publishers, Wageningen, pp 61-66 
Detroit Future City (2012) The land use element: the image of the City, Detroit Future City, 2012, Detroit, http://detroitworksproject.com/wp-content/uploads/2013/01/DFC_Plan_Land-Use. pdf. Accessed 19 June 2015

Di Iacovo F, Brunori G, Innocenti S (2013) Le strategie urbane: il piano del cibo. Agriregionieuropa 32(March): 9

Dupuis E, Goodman D (2005) Should we go 'Home' to eat? Toward a reflexive politics of localism. J Rural Stud 21(3):359-371

European Union (2010) Consolidated versions of the treaty on European Union and the treaty on the functioning of the European Union (2010/C83/01). Off J Eur Union, 53 (30 March 2010)

FAO (2009) How to feed the world in 2050. FAO, Rome, $35 \mathrm{p}$

Forster T, Hussein K, Mattheisen E (2015) City region food systems: an inclusive and integrated approach to improving food systems and urban-rural linkages. Urban Agric Mag 29:8-11

Freudenberg N, Silver M (2013) Jobs for a healthier diet and a stronger economy: opportunities for creating new good food jobs in New York City. New York City Food Policy Center at Hunter College, New York, $44 \mathrm{p}$

GLA (2011) The Mayor's food strategy: healthy and sustainable food for London: an implementation plan, 2011-13. Greater London Authority, London, 34 p

GLA, CIEH (2012) Takeaways toolkit: tools, interventions and case studies to help local authorities develop a response to the health impacts of fast food takeaways. Greater London. Authority and Chartered Institute of Environmental Health, London, $67 \mathrm{p}$

Halliday J (2015) A new institutionalist analysis of local level food policy in England between 2012 and 2014. Doctoral thesis. Food Policy specialization, City University, London, 294 p

Harper A, Alkon A, Shattuck A, Holt-Giménez E, Lambrick F (2009) Food policy councils: lessons learned. Food First, Institute for Food and Development Policy, Oakland, $63 \mathrm{p}$

Hay C (2002) Political analysis: a critical introduction. Palgrave Macmillan, Basingstoke, 336 p

Jennings S, Cottee J, Curtis T, Miller S (2015) Food in an urbanised world, the role of City food systems in resilience and sustainable development. Prince of Wales' International Sustainability Unit, London, $80 \mathrm{p}$

Johnson B (2013) 2020 vision: the Greatest City on earth, ambitions for London. Greater London Authority, London, $84 \mathrm{p}$

Laidlaw J (2015) Food security - a Core component of a Leading City's transformation agenda. UN Global Compact Cities Programme, Melbourne, $8 \mathrm{p}$

Lang T, Heasman M (2015) Food Wars. Routledge, Abingdon, $310 \mathrm{p}$

Lang T, Barling D, Caraher M (2009) Food policy: integrating health, environment and society. Oxford University Press, Oxford, 313 p

Libman K (2015) Has New York city fallen into the local trap? Public Health 129(4):310-317

Libman K, Freudenberg N, Sanders D, Puoane T, Tsolekile L (2015) The role of urban food policy in preventing diet-related non-communicable diseases in Cape Town and New York. Public Health 129(4):327-335

London, 2012 (2009) For starters: food vision fo the London 2012 Olympic games and Paralympic games. London, $\mathrm{p} 42$

Mah CL, Thang H (2013) Cultivating food connections: the Toronto food strategy and municipal deliberation on food. Int Plan Stud 18(1):96-110

Mansfield B, Mendes W (2013) Municipal food strategies and integrated approaches to urban agriculture: exploring three cases from the global north. Int Plan Stud 18(1):37-60

Marsden T (2013) Contemporary food systems: managing the capitalist conundrum of food security and sustainability. In: Murcott A, Belasco W, Jackson P (eds) The handbook of food research. Bloomsbury, London/New York, pp 135-147

Mendes W (2008) Implementing social and environmental policies in cities: the case of food policy in Vancouver, Canada. Int J Urban Reg Res 32(4):942-967

Morgan K (2009) Feeding the City: the challenge of urban food planning. Int Plan Stud 14(4):341-348 
Morgan K (2014) Nourishing the city: the rise of the urban food question in the Global North. Urban Stud 52:1379-1394

Morgan K, Sonnino R (2008) The school food revolution: public food and the challenge of sustainable development. Earthscan, London, $231 \mathrm{p}$

Morgan K, Sonnino R (2010) The urban foodscape: world cities and the new food equation. Camb J Reg Econ Soc 3(2):209-224

Morgan K, Marsden T, Murdoch J (2006) Worlds of food: place, power and provenance in the food chain. Oxford University Press, Oxford, 225 p

Orlando G (2011) Sustainable food vs. unsustainable politics in the city of Palermo: the case of an organic farmers' market. City Soc 23(2):173-191

Oursense City Council (2013) Ourense vegetable gardens. http://www.sustainable-everyday-project.net/urbact-sustainable-food/2013/10/24/ourense-vegetable-gardens-2. Accessed 29 June 2015

Paturel D, Marajo-Petitzon E, Chiffoleau Y (2015) La précarité alimentaire des agriculteurs. Revue Pour 225:77-81

Perrin C, Soulard CT (2014) Vers une gouvernance alimentaire locale reliant ville et agriculture. Le cas de Perpignan. Géocarrefour 89(1-2-3):125-134

Pierre J, Peters BG (2003) Introduction: the role of public administration in governing. In: Peters G, Pierre J (eds) Handbook of public administration. Sage, London, 640 p

Pothukuchi K, Kaufman JL (1999) Placing the food system on the urban agenda: the role of municipal institutions in food systems planning. Agric Hum Values 16:213-224

Reynolds B (2009) Feeding a world CITY: the London food strategy. Int Plan Stud 14(4):417-424

Rocha C, Lessa I (2009) Urban governance for food security: the alternative food system in Belo Horizonte, Brazil. Int Plan Stud 14(4):389-400

Roitman S, Bifarello M (2010) Urban agriculture and social inclusion in Rosario Argentina. Inclusive Cities Observatory, London, $7 \mathrm{p}$

Schiff R (2008) The role of food policy councils in developing sustainable food systems. J Hung Environ Nutr 3(2-3):206-228

Sonnino R (2013) Local foodscapes: place and power in the agri-food system. Acta Agric Scand Sect B Soil Plant Sci 63(S1):2-7

Sonnino R (2014) The new geography of food security: exploring the potential of urban food strategies. Geogr J 182(2):190-200

Sonnino R, Spayde J (2014) The 'new frontier'? Urban strategies for food security and sustainability. In: Marsden T, Morley A (eds) Sustainable food systems: building a new paradigm. Routledge, Abingdon/New York, $256 \mathrm{p}$

Soulard CT, Banzo M, Perrin C, Valette E (2015) Urban strategies and practices for agriculture and food: six mediterranean case studies. In: Proceedings of the second international conference on agriculture in an urbanizing society, Rome, 14-17 September

Steel C (2008) Hungry City: how food shapes our lives. Chatto \& Windus, London, $400 \mathrm{p}$

Steel C (2012) Sitopia - harnessing the power of food. In: Wiskerke JSC, Viljoen A (eds) Sustainable food planning: evolving theory and practice. Wageningen Academic Publishers, Wageningen, pp 37-46

Stoker G (2000) Urban political science and the challenge of urban governance. In: Pierre J (ed) Debating governance: authority, steering and democracy. Oxford University Press, Oxford, $272 \mathrm{p}$

Van der Schans JW (2015) Developing the Rotterdam City region food system: acting and thinking at the same time. Urban Agric Mag 29:14-17

Velasco M, De Vrieze A (2015) Unlocking La Paz. Urban Agric Mag 2(29):70-71

Warhurst P (2012) TED talk: how we can eat our landscapes. Video, http://www.ted.com/talks/ view/lang/en//id/1538. Accessed 29 June 2015

Wegener J, Seasons M, Raine KD (2013) Shifting from vision to reality: perspectives on regional food policies and food system planning barriers at the local level. Can J Urban Res 22(1):93-112 
Wekerle G (2004) Food justice movements: policy, planning, and networks. J Plan Educ Res 23(4):378-386

Wertheim-Heck S, Vellema S, Spaargaren G (2015) Food safety and urban food markets in Vietnam: the need for flexible and customized retail modernization policies. Food Policy 54:95-106

Winter M (2003) Embeddedness, the new food economy and defensive localism. J Rural Stud 19(1):23-32

Wiskerke J (2009) On places lost and places regained: reflections on the alternative food geography and sustainable regional development. Int Plan Stud 14(4):369-387

Wiskerke J, Viljoen A (2012) Sustainable urban food Povisioning: challenges for scientists, policymakers, planners and designers. In: Wiskerke JSC, Viljoen A (eds) Sustainable food planning: evolving theory and practice. Wageningen Academic Publishers, Wageningen, pp 19-36

World Food Summit (1996) Rome declaration on World Food Security. Food and Agriculture Organization of the United Nations, Rome

Yeatman HR (2003) Food and nutrition policy at the local level: key factors that influence the policy development process. Crit Public Health 13(2):125-138

Open Access This chapter is licensed under the terms of the Creative Commons Attribution 4.0 International License (http://creativecommons.org/licenses/by/4.0/), which permits use, sharing, adaptation, distribution and reproduction in any medium or format, as long as you give appropriate credit to the original author(s) and the source, provide a link to the Creative Commons licence and indicate if changes were made.

The images or other third party material in this chapter are included in the chapter's Creative Commons licence, unless indicated otherwise in a credit line to the material. If material is not included in the chapter's Creative Commons licence and your intended use is not permitted by statutory regulation or exceeds the permitted use, you will need to obtain permission directly from the copyright holder.

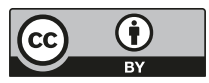

